\title{
EVALUASI SISTEM AKUNTANSI PENJUALAN, PIUTANG, DAN PENERIMAAN KAS PADA PT LIVIO FURNITURE
}

\author{
Aries Wicaksono \\ Jurusan Akuntansi, Fakultas Ekonomi dan Bisnis, Universitas Bina Nusantara \\ Jln. K.H. Syahdan No.9, Palmerah, Jakarta Barat 11480
}

\begin{abstract}
Sales functions, receivables and cash receipts, are very important within the company. Sales function is a function which becomes the prime mover in revenues and earnings yields target. Therefore, the effectiveness and efficiency in the sales process, accounts receivable, and cash receipts become very important concern for company. To assess the effectiveness and efficiency of the functions of sales, accounts receivable, and cash receipts should be evaluated. The evaluation was conducted both in terms of procedures, policies, and implementation of the functions of sales, accounts receivable, and cash receipts. Evaluation was done by using the instrument in the form of a questionnaire and analyzing the procedures and policies that exist in PT Livio Furniture. The results of the evaluation of the functions of sales, accounts receivable, and cash receipts obtained the conclusion that internal controls at PT Livio Furniture is good enough and adequate, although still found that become a concern for the company.
\end{abstract}

Keywords: evaluation, sales, account receivables,cash receipts

\begin{abstract}
ABSTRAK
Fungsi Penjualan, piutang dan penerimaan kas, merupakan fungsi yang sangat penting dalam perusahaan. Fungsi penjualan merupakan fungsi yang menjadi penggerak utama dalam menghasilkan penerimaan dan laba yang ditargetkan perusahaan. Oleh karena itu, efektivitas dan efisiensi dalam proses penjualan, piutang, dan penerimaan kas menjadi perhatian yang sangat penting. Untuk menilai efektivitas dan efisiensi fungsi penjualan, piutang, dan penerimaan kas perlu dilakukan evaluasi terhadapnya. Evaluasi tersebut dilakukan baik dari segi prosedur, kebijakan serta pelaksanaan dari fungsi penjualan, piutang, dan penerimaan kas. Evaluasi dilakukan dengan menggunakan instrumen berupa kuesioner dan menganalisis prosedur serta kebijakan yang ada pada PT Livio Furniture. Hasil evaluasi dari fungsi penjualan, piutang, dan penerimaan kas didapatkan simpulan bahwa pengendalian internal pada PT Livio Furniture sudah cukup baik dan memadai, walaupun masih ditemukan hal yang menjadi perhatian untuk perusahaan.
\end{abstract}

Kata kunci: evaluasi, penjualan, piutang, penerimaan kas 


\section{PENDAHULUAN}

\section{Latar Belakang}

Perkembangan bisnis yang semakin pesat dewasa ini membuktikan adanya peningkatan yang riil atas kegiatan ekonomi yang berlangsung selama ini. Hal tersebut secara langsung memberikan pengaruh terhadap pertumbuhan omzet serta laba suatu perusahaan yang mengikuti tren positif atas pertumbuhan ekonomi yang terjadi selama ini. Laba yang tumbuh secara positif mengikuti perkembangan bisnis dapat terealisasi jika dipastikan bahwa semua opeasional dalam perusahaan berjalan secara efektif dan efisien.

Untuk tetap dapat memperoleh laba atau profit, maka perusahaan harus tetap berusaha untuk menjaga kelangsungan usahanya pada masa mendatang. Usaha tersebut tentunya dilakukan untuk menghasilkan laba atau profit sehingga sangat berkaitan dengan sistem penjualan, piutang, dan penerimaan kas. Untuk memastikan bahwa penjualan berlangsung dengan baik, perusahaan harus memerhatikan proses pengendalian internal dalam sistem penjualannya. Peran adaptasi terhadap teknologi yang berkembang selama ini juga menjadi hal yang penting untuk meningkatkan pengendalian internal.

Struktur pengendalian internal suatu perusahaan sangat memengaruhi perkembangan serta keberlangsungan suatu perusahaan. Suatu perusahaan dapat berjalan dengan baik jika didukung oleh pengendalian internal yang sesuai dengan kebutuhan perusahan tersebut. Pengendalian internal yang sesuai dan baik, dapat mengendalikan dan memastikan bahwa proses penjualan sampai dengan penerimaan kas dari hasil penjualan tersebut telah dilakukan dengan baik. Peluang terjadinya penyimpangan menjadi lebih besar jika proses tersebut tidak dilengkapi dengan pengendalian internal yang sesuai dan baik, dan apabila terjadi kecurangan, tingkat profit dan laba yang diharapkan tidak akan tercapai sesuai target. Oleh karena itu, untuk mendukung perusahaan dalam mencapai tujuan tersebut, diperlukan adanya pengelola atau manajemen yang dapat melakukan perencanaan, pengoordinasian, dan pengendalian aktivitas yang baik serta dapat mendukung operasional bisnis perusahaan sehingga menjadi lebih efektif, efisien, dan transparan. Selain mempunyai pengendalian internal yang baik, untuk memastikan bahwa aktivitas pengendalian internal telah berjalan dengan baik, maka diperlukan pemeriksaan operasional atas aktivitas pengendalian internal yang ada. Sehingga, prosedur serta kebijakan yang ada dalam pengendalian internal tersebut dapat mencapai tujuan yang dituju.

Dalam suatu perusahaan fungsi penjualan merupakan fungsi yang sangat penting karena dijadikan sumber bagi perusahaan untuk memenuhi kebutuhan operasional perusahaan serta menjadi sumber pendapatan bagi perusahaan. Penjualan sendiri terdiri dari dua jenis penjualan yaitu penjualan kredit dan penjualan secara tunai. Penjualan kredit mempunyai dampak terhadap timbulnya perkiraan tunai sebelum menjadi penerimaan kas bagi perusahaan, sedangkan penjualan tunai memberikan dampak langsung timbulnya perkiraan penerimaan kas dalam perusahaan. Oleh karena itu, fungsi penjualan harus berjalan sesuai dengan prosedur serta kebijakan dalam perusahaan sehingga aktivitas pengendalian internal terhadap penjualan dapat berjalan dengan baik.

PT Livio Furniture merupakan satu di antara perusahaan manufaktur yang memproduksi furnitur khusus untuk furnitur yang bersifat premium. Furnitur yang disediakan dan diproduksi, antara lain meja dan bangku untuk ruang tamu, meja makan, lemari, tempat tidur, meja rias, lemari pajangan. Semua jenis furnitur tersebut diproduksi dan dipasarkan langsung oleh PT Livio Furniture melalui showroom yang dimiliki oleh PT Livio Furniture. Sistem penjualan yang dilakukan oleh PT Livio Furniture dilakukan secara tunai maupun kredit. Proporsi penjualan yang dilakukan lebih banyak dilakukan secara kredit karena selain menjual langsung melalui showroom yang ada, PT Livio 
Furniture juga menyuplai furnitur kepada klien yang berbentuk toko-toko furnitur dan penjualan yang dilakukan kepada toko-toko tersebut dilakukan secara kredit. Permasalahan yang dihadapi oleh PT Livio Furniture terkait dengan sistem penjualannya adalah banyaknya piutang tak tertagih, terutama ketika pada tahap pelunasan piutang tahap akhir. Oleh karena itu, diperlukan pengendalian atas proses tersebut sehingga dapat mengatasi atau meminimalisasi risiko piutang tak tertagih yang ada.

Tujuan penelitian, antara lain yaitu: (1) melakukan evaluasi atas pelaksanaan pengendalian internal pada PT Livio furnitur pada fungsi penjualan, piutang, dan penerimaan kas, apakah sudah berjalan dengan efektif dan efisien; (2) melakukan evaluasi terhadap kegiatan operasional bisnis pada fungsi penjualan khususnya penjualan, piutang, dan penerimaan kas pada PT Livio Furniture apakah telah dilaksanakan sesuai prosedur dan kebijakan yang berlaku pada PT Livio Furniture; (3) memberikan masukan dan saran kepada manajemen PT Livio Furniture atas kegiatan operasional bisnis pada fungsi penjualan sehingga dapat berjalan dengan lebih efektif dan efisien serta dapat meminimalisasi risiko-risiko yang ada pada kegiatan operasional penjualan.

Manfaat dari penelitian, antara lain yaitu: (1) bagi perusahaan, membantu perusahaan untuk mengetahui apakah pengendalian internal pada fungsi penjualan, piutang, dan penerimaan kas yang berlangsung selama ini sudah berjalan dengan baik serta dapat meningkatkan efektivitas dan efisiensi dari proses pengendalian internal yang berjalan; (2) bagi peneliti, memberikan gambaran wawasan yang lebih luas mengenai proses pengendalian yang berjalan pada fungsi penjualan, piutang, dan penerimaan kas pada perusahaan khususnya perusahaan furnitur; dan (3) bagi pihak lain, sebagai sarana yang bersifat informatif serta menjadi pengembangan pihak lain untuk melakukan penelitian lebih lanjut.

\section{Analisis Pustaka}

Dalam literatur yang ada mengenai pengendalian internal (internal control) menurut Gondodiyoto dan Hendarti (2007), pengendalian intern adalah struktur organisasi, metode, dan ukuran-ukuran yang dikoordinasikan untuk menjaga kekayaan organisasi, mengecek ketelitian dan keandalan data akuntansi, mendorong efisiensi dan dipatuhinya kebijakan manajemen. Tidak memerlukan detail audit dalam bentuk pengujian substantif atas bahan bukti atau data perusahaan yang cukup besar oleh akuntan publik.

Sedangkan menurut Weygandt, Kieso dan Kimmel (2008), pengendalian internal adalah semua metode dan ukuran-ukuran yang diadopsi ke dalam organisasi untuk: (1) menjaga aset dari pencurian oleh pegawai, perampokan, dan penggunaan yang tidak bertanggung jawab; (2) meningkatkan akurasi dan reliabilitas dari catatan akuntansi. Hal ini dilakukan dengan mengurangi risiko kesalahan (kesalahan yang tidak disengaja) dan ketidaksesuaian (kesalahan dan salah interpretasi yang disengaja) dalam proses akuntansi.

Berdasarkan literatur di atas, pengendalian internal merupakan suatu proses yang terdiri dari prosedur, metode, kebijakan serta aturan yang diterapkan dalam suatu organisasi untuk memastikan bahwa semua aset telah terjaga dan proses pencatatan, perekaman, serta pengolahan data menjadi informasi dapat menghasilkan informasi yang akurat serta terjamin reliabilitasnya sehingga organisasi dapat mencapai tujuan organisasi yang telah direncanakan dengan baik.

Kerangka atau model pengendalian internal yang lazim digunakan yaitu model COSO (The Committee of Sponsoring Organization). Menurut Gondodiyoto dan Hendarti (2007), model COSO terdiri dari lima komponen atau unsur pengendalian internal yang akan menunjang pencapaian tujuan perusahaan, yaitu: lingkungan pengendalian (control environment), penilaian risiko (risk assessment), aktivitas pengendalian (control activities), informasi dan komunikasi (information and communication), dan pemantauan (monitoring). 
Untuk mengevaluasi suatu pengendalian internal menurut (Agoes, 2004) dalam organisasi dapat dilakukan dengan menggunakan beberapa instrumen antara lain: (1) Internal Control Questionnaire (ICQ), biasanya digunakan oleh KAP untuk mengevaluasi pengendalian internal dari kliennya. Instrumen ini digunakan karena lebih sederhana dan praktis; (2) flowchart (bagan arus), biasanya digunakan untuk menggambarkan proses bisnis dalam suatu unit usaha. Auditor yang menggunakan flowchart merupakan auditor yang sudah terlatih, dengan menggunakan flowchart kelemahan-kelemahan yang ada lebih mudah untuk dianalisis; dan (3) uraian cerita (narrative), biasanya digunakan untuk menggambarkan proses bisnis dari suatu organisasi yang memiliki proses bisnis yang sederhana.

Fungsi penjualan merupakan bagian yang tak terpisahkan dengan sistem akuntansi yang ada. Romney dan Steinbart (2003) menyatakan bahwa fungsi penjualan dan penerimaan kas merupakan satu kesatuan dalam siklus penerimaan (revenue cycle). Aktivitas yang termasuk penjualan dapat dibagi menjadi beberapa aktivitas, yaitu menerima pesanan dari pelanggan, mengirimkan pesanan, menerima pembayaran, menyimpan pembayaran yang diterima, dan menyesuaikan perkiraan pelanggan. Agar lebih jelas, digambarkan dalam Tabel 1 berikut.

\begin{tabular}{|c|c|}
\hline \multicolumn{2}{|c|}{ Tabel 1 Tabel Aktivitas dalam Siklus Penerimaan } \\
\hline Aktivitas & Dokumen Sumber \\
\hline Menerima Pesanan Pelanggan & Permintaan Penjualan \\
\hline Mengirimkan atau mengapalkan pesanan & Bukti Pengiriman atau Surat Jalan \\
\hline Menerima pembayaran & Bukti Pembayaran \\
\hline Menyimpan pembayaran yang diterima & Slip Penyimpanan atau Deposit Slip \\
\hline Menyesuaikan akun pelanggan & Memo Kredit \\
\hline
\end{tabular}

Sedangkan menurut Ikatan Akuntan Indonesia (IAI) PSAK No. 23, penjualan barang meliputi barang yang diproduksi perusahaan untuk dijual, serta barang yang dibeli untuk dijual kembali, seperti barang yang dijual oleh pengecer atau tanah dan properti lain yang dibeli untuk dijual kembali. Berdasarkan pengertian penjualan di atas, maka dapat diambil kesimpulan bahwa kegiatan penjualan adalah kegiatan penyerahan hak milik atas barang atau jasa dari penjual kepada pembeli. Atas barang yang dialihkan hak kepemilikannya kepada pembeli, maka pembeli wajib memberikan imbalan atau uang kepada penjual atas barang atau jasa yang telah diberikan kepada pembeli. Penjualan dalam hal ini dapat dikategorikan menjadi dua jenis penjualan yaitu penjualan tunai dan kredit. Penjualan tunai merupakan penjualan di mana pembeli berkewajiban melakukan pembayaran sebelum atau bersamaan dengan dengan waktu penyerahan barang sehingga tidak menimbulkan kewajiban di kemudian hari bagi pembeli. Penjualan kredit dilakukan dengan penjual terlebih dahulu menyerahkan barang atau jasa kepada pembeli, kemudian pembeli melakukan pembayaran di kemudian hari sehingga menimbulkan kewajiban bagi pembeli di kemudian hari. 
Rangkuman kajian teoretis yang telah dianalisis dapat dilihat dalam Tabel 2.

Tabel 2 Rangkuman kajian teoritik

\begin{tabular}{|c|c|c|c|}
\hline No & Sumber Teori & Penjelasan & Hubungan Penelitian \\
\hline 1 & $\begin{array}{l}\text { Gondodiyoto dan } \\
\text { Hendarti (2007) }\end{array}$ & $\begin{array}{l}\text { Kerangka pengendalian internal berdasarkan } \\
\text { COSO terdiri dari Lingkungan pengendalian, } \\
\text { Penilaian Resiko, Lingkungan pengendalian, } \\
\text { Informasi dan komunikasi, Pemantauan. }\end{array}$ & $\begin{array}{l}\text { Evaluasi pengendalian } \\
\text { internal dilakukan } \\
\text { berdasarkan Lingkungan } \\
\text { pengendalian, Penilaian } \\
\text { Resiko, Lingkungan } \\
\text { pengendalian, Informasi dan } \\
\text { komunikasi, Pemantauan. }\end{array}$ \\
\hline 2 & Agoes (2004) & $\begin{array}{l}\text { Instrumen untuk mengevaluasi pengendalian } \\
\text { internal dapat menggunakan Internal Control } \\
\text { Questionnaire, Flowchart, dan Uraian Cerita. }\end{array}$ & $\begin{array}{l}\text { Evaluasi dilakukan dengan } \\
\text { menggunakan Internal } \\
\text { Control Questionnaire dan } \\
\text { Uraian Cerita. }\end{array}$ \\
\hline 3. & $\begin{array}{l}\text { Ikatan Akuntan Indonesia } \\
\text { (2010) }\end{array}$ & $\begin{array}{l}\text { Penjualan dapat dikategorikan menjadi dua } \\
\text { jenis yaitu penjualan tunai dan penjualan } \\
\text { kredit }\end{array}$ & $\begin{array}{l}\text { Evaluasi terhadap penjualan } \\
\text { dilakukan terhadap baik } \\
\text { penjualan tunai maupun } \\
\text { penjualan kredit }\end{array}$ \\
\hline
\end{tabular}

\section{METODE}

Metodologi yang digunakan dalam penelitian ini adalah metode deskriptif dan wawancara. Penelitian deskriptif dilakukan dengan meneliti pengendalian internal yang berupa prosedur, kebijakan dan aturan yang ada pada PT Livio Furniture kemudian mengevaluasinya berdasarkan permasalahan yang ada selama ini terjadi dengan menghubungkannya satu sama lain baik dari sisi prosedur, kebijakan serta aturan. Metode wawancara digunakan untuk memeperoleh gambaran langsung dari pelaku dalam fungsi penjualan, piutang dan penerimaan kas yang ada pada PT Livio Furniture. Dengan kedua metode tersebut dapat dihasilkan gambaran permasalahan yang selama ini terjadi serta kendala-kendala untuk mengatasi permasalahan tersebut.

\section{HASIL DAN PEMBAHASAN}

\section{Hasil Kuesioner Pengendalian Internal atas Fungsi Penjualan, Piutang, dan Penerimaan Kas}

Untuk melakukan analisis dan evaluasi atas fungsi penjualan, piutang, dan penerimaan kas pada PT Livio Furniture, maka diperlukan suatu instrumen untuk menangkap proses bisnis yang berjalan serta kelemahan-kelamahan yang ada pada PT Livio Furniture. Hal itu terutama terkait dengan fungsi penjualan, piutang, dan penerimaan kas. Setelah diperoleh informasi dari kuesioner yang telah terisi, maka dapat dianalisis kelemahan serta kekurangan yang ada pada PT Livio Furniture.

Pengendalian internal yang ada di PT Livio Furniture bisa dikatakan cukup baik dan memadai. Hal itu tercermin dari jawaban-jawaban yang diperoleh dari kuesioner pengendalian internal. Selain dari informasi yang diperoleh dari kuesioner pengendalian internal, dapat diketahui beberapa hal positif yang selama ini telah berlangsung pada PT Livio Furniture, antara lain: (1) adanya otorisasi pada setiap dokumen yang dikeluarkan sehingga tahapan pada proses penjualan dilakukan sesuai dengan personel yang bertanggung jawab pada setiap prosedur; (2) salah satu komponen pengendalian 
internal, yaitu pemisahan fungsi yang terkait atau pemisahan wewenang telah diterapkan pada PT Livio Furniture; (3) strategi penjualan pada PT Livio Furniture telah dikomunikasikan dengan baik sehingga tingkat penjualan dari setiap periode meningkat; (4) secara prosedural, semua prosedur yang telah dibuat oleh PT Livio Furniture telah diketahui oleh stakeholder di PT Livio Furniture; (5) proses pemutakhiran data penjualan berlangsung baik karena barang yang sudah dikembalikan mengurangi nilai penjualan; (6) proses pengelolaan piutang sudah baik, piutang dikendalikan dengan menggunakan kartu piutang, dan secara periodik dilakukan rekonsiliasi dengan buku besar piutang; (7) perusahaan memonitoring semua piutang dengan membuat ukuran umur piutang dari masing-masing transaksi kredit sehingga piutang yang akan jatuh tempo dapat terpantau dengan baik; (8) risiko piutang tak tertagih telah diantisipasi oleh perusahaan dengan mengalokasikan adanya piutang yang tak tertagih dalam periode tertentu; (9) fungsi penerimaan kas terpisah dengan fungsi penjualan dan fungsi akuntansi sehingga dapat meminimalisasi kemungkinan terjadinya fraud karena ada fungsi pengecekan satu dengan yang lain; (10) rekonsiliasi antara saldo kas di bank dengan saldo kas yang ada pada catatan di perusahaan dilakukan secara periodik untuk menghindari kesalahan pencatatan maupun kecurangan; (11) penerimaan pembayaran yang berupa cek maupun bilyet giro dicatat dalam buku khusus untuk mengetahui pembayaran yang dilakukan dengan menggunakan bilyet giro dan cek; (12) pembayaran yang telah dilakukan oleh konsumen dilakukan pengecekan ulang baik dari segi jumlah pembayaran, ataupun metode pembayaran. Hal ini dilakukan untuk menghindari ketidakcocokan pembayaran yang dilakukan oleh konsumen.

Sedangkan kelemahan-kelemahan yang dapat ditangkap melalui kuesioner pengendalian internal pada fungsi penjualan, piutang dan penerimaan kas, antara lain: (1) batasan kredit (credit limit) yang telah ditetapkan terkadang dapat dilanggar karena beberapa alasan yaitu menjaga hubungan baik dengan konsumen dan menjaga kinerja penjualan; (2) tidak melakukan pengecekan atas barang yang telah dipesan oleh konsumen. Hal ini dapat menyebabkan terjadinya kesalahan pengiriman karena salah meng-input barang yang dibeli, atau ketidakjelasan konsumen atas produk yang dijual perusahaan; (3) dokumen penjualan yang telah dibatalkan status pembeliannya oleh konsumen tidak diarsip dalam penjualan yang dibatalkan. Hal ini berisiko adanya penyalahgunaan dokumen-dokumen tersebut oleh pihak yang tidak berwenang; (4) terhadap konsumen yang belum membayar atau melunasi hutangnya, perusahaan tidak mengirimkan surat pengakuan piutang kepada konsumen secara periodik. Hal ini dapat menyebabkan risiko piutang tak tertagih semakin besar karena konsumen dapat bersifat abai terhadap hutangnya jika tidak diingatkan secara intensif; (5) tidak dilakukan rekonsiliasi antara laporan penjualan dengan laporan penerimaan kas. Hal ini dapat menyebabkan, jika ada kesalahan atau kecurangan, tidak terdeteksi kecuali kita mengecek kembali semua transaksi satu per satu.

\section{Evaluasi Fungsi Penjualan, Piutang, dan Penerimaan Kas}

Proses bisnis yang terjadi pada proses penjualan, piutang, dan penerimaan kas sudah memiliki pengendalian internal yang cukup baik dan memadai. Jika diteliti ke dalam satu per satu memang masih ada yang belum sempurna karena itu masih terjadi permasalahan yang telah diidentifikasi pada tahap awal penelitian. Fungsi penjualan yang menjadi motor penggerak bagi perusahaan untuk menghasilkan penerimaan sebagai penggerak laba merupakan bagian yang sangat penting bagi perusahaan yang menjadi titik perhatian bagi perusahaan.

Pembahasan penting, yaitu pengendalian internal pada proses penjualan, piutang, dan penerimaan kas, adalah masalah munculnya piutang yang tidak tertagih atau terlambatnya pembayaran piutang oleh pelanggan. Hal itu menjadi perhatian khusus karena sangat memengaruhi operasional bisnis perusahaan yang memerlukan kas untuk menjalankan bisnis perusahaan terutama kaitannya dengan biaya produksi yang mencapai 70 persen sampai 80 persen dari harga jual yang ditetapkan perusahaan. 
Evaluasi atas fungsi penjualan, piutang, dan penerimaan kas akan dibahas berdasarkan komponen-komponen pengendalian internal.

\section{Lingkungan Pengendalian Internal}

Ada beberapa hal yang menjadi bahasan pada lingkungan pengendalian internal yaitu integritas dan etika, gaya manajemen, struktur organisasi dan pemisahan wewenang, serta kebijakan terhadap sumber daya manusia. Pada praktiknya, semua hal tersebut menjadi hal terkait satu dengan yang lain dan tidak terpisah untuk dibahas.

Dalam hal integritas dan etika, manajemen selalu mengomunikasikan mengenai pentingnya integritas dan etika dalam menjalankan tugas masing-masing dalam perusahaan. Hal tersebut terlihat dengan kode etik yang dibuat oleh perusahaan dan disosialisasikan dengan intensif karena selalu dibahas dalam setiap pertemuan manajemen, briefing, maupun pertemuan-pertemuan informal antara manajemen dengan karyawan. Selain itu, dari segi kebijakan penjualan, setiap karyawan di bidang penjualan dilarang menerima dan memberi imbalan dari dan kepada pembeli. Untuk menghindari konflik kepentingan terkait dengan kinerja penjualan karyawan tersebut, karyawan penjualan diberikan komisi penjualan untuk memberikan penghargaan atas kinerja penjualan yang baik.

Gaya manajemen yang ditunjukkan juga sangat baik. Manajemen tidak terlihat eksklusif, tetapi bersifat inklusif. Manajemen sangat akomodatif dan komunikatif untuk mengomunikasikan segala sesuatu yang menjadi permasalahan dan kendala dalam proses bisnis yang berlangsung dengan karyawan. Ditambah lagi, manajemen berkomitmen untuk memimpin dengan contoh sehingga segala kebijakan yang dibuat tidak hanya berdampak terhadap karyawan tetapi juga dengan manajemen.

Struktur organisasi dalam perusahaan telah dibagi dengan jelas, dan telah berjalan dengan baik. Adanya pemisahan tugas satu fungsi dengan yang lain memberikan rentang kendali internal untuk terjadi pengecekan antara satu fungsi dengan fungsi lain yang terkait agar kemungkinan terjadinya kecurangan atau kesalahan dapat teridentifikasi, sehingga dapat diminimalisasi. Pengelolaan sumber daya manusia pada PT Livio Furniture juga menjadi fokus untuk manajemen. Program pelatihan bagi karyawan dilakukan secara rutin. Manajemen menyadari untuk meningkatkan kemampuan karyawan. Secara periodik, pekerja pemahat atau pengukir yang telah berpengalaman memberikan pelatihan bagi karyawan pemahat atau pengukir yang baru dan belum cukup berpengalaman. Hal tersebut dilakukan untuk meningkatkan kualitas produk secara tidak langsung.

\section{Penilaian Risiko}

Penilaian risiko merupakan hal yang sangat penting untuk dilakukan manajemen karena apabila perusahaan dapat memitigasi risiko yang ada dengan baik, maka perusahaan akan dapat mengatasi berbagai permasalahan yang telah teridentifikasi akan terjadi. Pada kenyataannya, semua risiko yang ada, baik dari internal perusahaan, maupun eksternal masih belum dapat dinilai atau dimitigasi dengan baik sehingga manajemen masih terlihat kesulitan jika terjadi permasalahan baru yang belum teridentifikasi. Sebagai contoh, adanya risiko piutang tak tertagih yang meningkat masih kesulitan untuk diatasi oleh manajemen sehingga mengakibatkan piutang tak tertagih meningkat dari waktu ke waktu sedangkan kebutuhan akan biaya modal sangat berpengaruh terhadap operasional perusahaan. Selain itu, kebijakan penjualan yang bersifat eksklusif ke beberapa agen yang membuat perusahaan harus memasok barang secara cepat dengan mengabaikan pesanan konsumen lain, juga dapat menjadi permasalahan karena jika dilihat dari piutang agen-agen yang ada tidak menunjukkan status yang sangat lancar dalam pembayaran. 


\section{Aktivitas Pengendalian}

Dalam beberapa hal aktivitas pengendalian yang ada pada PT Livio Furniture sudah cukup baik dan memadai, tetapi ada beberapa hal temuan yang menjadi perhatian karena dapat menyebabkan adanya kecurangan pada aktivitas penjualan yang ada pada perusahaan. Dari segi pemisahan tugas dan wewenang memang sudah terlihat jelas, tetapi dalam pelaksanaannya masih ada terjadi ketidaksesuaian dengan kebijakan yang telah ditetapkan. Sebagai contoh yaitu, pelanggan yang telah mempunyai piutang yang melewati batas kredit seharusnya tidak boleh diberikan kredit lagi karena hal tersebut akan meningkatkan risiko piutang tak tertagih oleh konsumen tersebut. Manajemen harus konsisten terhadap kebijakan yang telah ditetapkan untuk menjaga keberlangsungan usaha perusahaan.

Otorisasi atas semua transaksi telah dilakukan dengan sesuai kebijakan. Transaksi dilakukan dengan terlebih dahulu melewati otorisasi dari pihak yang berwenang, tetapi memang dasar dalam mengotorisasi transaksi tersebut harus sesuai dengan kebijakan yang telah ditetapkan oleh perusahaan. Kemudian dari segi pendokumentasian juga sudah baik, tetapi dalam hal pengarsipan masih menjadi permasalahan karena ada temuan jika terjadi pembatalan pesanan, dokumen yang telah disiapkan tidak dipindahkan ke dalam arsip khusus. Dokumen tersebut sangat riskan untuk disalahgunakan. Oleh karena itu, sebaiknya perusahaan memperbaiki manajemen pengarsipan untuk menghindari hal-hal yang tidak diinginkan oleh perusahaan.

Pengendalian fisik terhadap aktiva, dalam hal ini, produk yang dijual juga sangat penting. Masih ada prosedur yang kurang di mana petugas gudang tidak memiliki catatan mengenai stok barang yang ada di gudang, yang dicatat hanyalah barang yang masuk dan keluar gudang. Jika hal tersebut terus berlanjut, barang yang ada di gudang tidak termonitor secara efektif. Maka dari itu, diperlukan pemeriksaan terhadap operasional bisnis perusahaan oleh pihak yang independen untuk menilai seberapa efektifkah operasional bisnis yang berjalan pada saat ini.

\section{Informasi dan Komunikasi}

Proses berjalannya informasi dalam satu bagian dengan bagian yang lain juga menjadi perhatian. Perusahaan memang telah menggunakan sistem informasi tetapi tidak menyeluruh masih ada fungsi yang memang terkait dengan fungsi penjualan yang belum menggunakan sistem informasi terutama bagian gudang, karena stok gudang yang datanya mutakhir sangat diperlukan ketika akan dilakukan penjualan kepada konsumen. Sehingga tidak ada konsumen yang kecewa ketika sudah melakukan pesanan tetapi stoknya kosong.

Pelaporan yang berjenjang sudah dilakukan dan diterapkan dengan baik oleh manajemen tetapi sebaiknya dalam pelaporan yang ada perlu dibandingkan satu sama lain sehingga dapat diuji validitas laporan tersebut. Sebagai contoh, laporan mengenai penjualan harus di bandingkan dengan laporan penerimaan kas untuk mengetahui bahwa data penerimaan kas telah cocok jika dicek langsung dengan laporan penjualaan.

\section{Pemantauan}

Pemantauan atas aktivitas penjualan juga harus dilakukan secara efektif oleh perusahaan, dimulai dari level bawah, menengah, dan atas. Selama ini pemantauan sangat efektif dan intensif dilakukan pada level atas tetapi pada level bawah belum dilakukan pemantauan secara efektif. Sebagai contoh, kepala penjualan tidak mengawasi aktivitas penjualan yang dilakukan oleh bawahannya secara penuh, sehingga banyak staf penjualan yang menyerahkan laporan terlambat kemudian beberapa dari staf penjualan tidak mencapai target yang telah ditetapkan. Oleh karena itu, pemantauan atas kinerja harus konsisten dilakukan pada semua level sehingga perusahaan berjalan konsisten untuk menuju tujuan yang diharapkan oleh perusahaan. 


\section{PENUTUP}

Berdasarkan hasil pembahasan penelitian mengenai evaluasi fungsi penjualan, piutang, dan penerimaan kas pada PT Livio Furniture, dapat disimpulkan bahwa pengendalian internal yang ada sudah cukup baik dan memadai. Hal tersebut dapat dianalisis dari prosedur dan kebijakan serta pelaksanaannya selama ini pada PT Livio Furniture meskipun ada beberapa hal yang menjadi catatan penting yang perlu menjadi perhatian bagi manajemen PT Livio Furniture. Hal yang menjadi perhatian penting adalah konsistensi dalam pelaksanaan prosedur dan kebijakan pada proses penjualan. Permasalahan awal yang diidentifikasi adalah tingkat piutang tak tertagih yang naik. Berdasarkan analisis, hal tersebut disebabkan ketidakkonsistenan kebijakan pembatasan kredit yang dilakukan oleh PT Livio Furniture sehingga ada agen atau konsumen yang melebihi batas kredit yang telah ditentukan. Selain itu, hal tersebut juga meningkatkan risiko terjadinya piutang tak tertagih yang semakin besar. Oleh karena itu, untuk mengatasi hal itu, manajemen harus konsisten melakukan pembatasan kredit dan memberikan sosialisasi mengenai kebijakan bonus penjualan bagi staf penjualan sehingga tidak ada usaha lagi untuk melebihi batasan kredit yang telah ditentukan. Selanjutnya, yang menjadi perhatian adalah manajemen stok atau persediaan di gudang. Hal tersebut sangat berkaitan dengan fungsi penjualan sehingga tidak ada lagi kesalahan karena data persediaan yang ada di gudang. Selain itu, sistem informasi juga belum diterapkan di fungsi gudang. Oleh karena itu, perlu dilakukan penelitian lebih lanjut untuk mengevaluasi sistem persediaan yang ada pada di PT Livio Furniture.

\section{DAFTAR PUSTAKA}

Agoes, S. (2004). Auditing: Pemeriksaan akuntan oleh akuntan publik. Lembaga Penerbit Fakultas Ekonomi Universitas Indonesia.

Gondodiyoto, S., \& Hendarti, H. (2007). Audit sistem informasi lanjutan. Media Mitra Wacana.

Ikatan Akuntan Indonesia. (2010). Standar Akuntansi Keuangan. Jakarta: Salemba Empat.

Romney, M. B., \& Steinbart, P. J. (2003). Accounting information system. Prentice Hall.

Weygandt, J. J., Kieso, D. E., \& Kimmel, P. D. (2008). Accounting Principles. Wiley. 